\title{
ANALISIS PARAMETER STABILITAS KAPAL UNTUK MENINGKATKAN OPERASIONAL PENANGKAPAN KAPAL PUKAT CINCIN DI PERAIRAN LAUT BANDA
}

\author{
Obed Metekohy ${ }^{1, *}$ \\ 1Jurusan Teknik Perkapalan Universitas Pattimura, Ambon 97233 \\ *Email: bobmetekohy2710@gmail.com
}

\begin{abstract}
Abstrak. Operasional penangkapan nelayan kapal pukat cincin di perairan laut Banda merupakan suatu potensi yang menjanjikan dengan stok ikan yang berlimpah. Akan tetapi kondisi fishing ground dengan cuaca yang ekstrim sangat berpengaruh terhadapoperasional penangkapan karena tidak di dukung oleh sarana penangkapan yang memadai. Kapal-kapal pukat cincin secara umum dibuat secara tradisional, denganpengalaman turun temurun. Pembuatan kapalnya sangat mempengaruhi karakteristik operasional penangkapan khususnya pada saat setting alat tangkap, penarikan jarring dengan hasil tangkapan dari dalam laut, dan pada saat kapal berangkat ke dan kembali dari fishing garound.Penelitian ini bertujuan untuk menganalisa parameter stabilitaskapal sehingga dapatmeningkatkan operasional penangkapan dan menjamin keselamatan nelayan. Metode yang digunakan dalam penelitian ini adalah metode diskriptif. Analisa terhadap parameter stabilitasmengacu pada peraturan perancangan kapal Ikan.Hasil penelitian menunjukkan bahwa parameterkarakteristik rasio lebar dan tinggi geladak (B/D) 46.67\%, GM dan TR 57.77\% kurang daristandard teknis perancangan sehingga sangat berpengaruh terhadap stabilitas kapal pada saat operasional penangkapan.
\end{abstract}

Kata kunci: Parameter Stabilitas, Ukuran Pokok,Pukat Cincin

\begin{abstract}
The fishing operation of ring trawlers in Banda Sea waters is a promising potential with abundant fish stocks. However, fishing ground conditions with extreme weather greatly affect fishing operations because they are not supported by adequate fishing facilities. In general, ring trawlers are made in a traditional way, with hereditary experience. The shipbuilding greatly affects the operational characteristics of fishing, especially when setting fishing gear, pulling nets with catches from the sea, and when ships departing to and returning from the fishing grounds. This study aims to analyze the stability parameters of the ship so that it can improve fishing operations and ensure the safety of fishermen. The method used in this research is descriptive method. Analysis of the stability parameters refers to the design regulations of the Fish vessel. The results showed that the characteristic parameters of the ratio of the width and height of the deck $(L / B)$ were $93 \%, G M 62.23 \%$, TR $35.55 \%$ less than the technical design standards so that it greatly affected the stability of the ship during fishing operations.
\end{abstract}

Keywords: Stability Parameters, Basic Size, Purse Seine

\section{PENDAHULUAN}

Kegiatan perikanan tangkap diperairan laut Banda memang menjanjikan dengan potensi perikanan sebesar 788,939 ton [1]. Kegiatan perikanan tangkap ini penuh dengan tantangan serta dihadapkan dengan resiko dan ketidakpastian [2]. Memperkirakan bahwa sekitar 30 juta nelayan bekerja pada 4 juta kapal penangkap ikan yang beroperasi didunia. Sekitar 98\% dari nelayan tersebut bekerja pada kapal dengan panjang kurang dari 24 meter, dimana untuk ukuran ini tidak tercakup didalam peraturan 
internasional. Pukat cincin merupakan alat tangkap ikan yang produktif dan tergolong alat tangkap aktif. Pengoperasian alat tangkap pukat cincin dilakukan dengan cara melingkarkan jaring pada gerombolan ikan sehingga ikan yang terkepung tidak dapat melarikan diri ke arah horizontal kemudian tali kolor ditarik sehingga jaring membentuk kerucut sehingga ikan tidak dapat meloloskan diri ke arah vertikal dan tertangkap [3]. Kapal ikan pukat cincin (purse seiner) merupakan tipe kapal ikan yang dalam pengoperasiannya perlu ditinjau secara khusus, karena kapal ini menyerap modal yang besar pada usaha penangkapan ikan [4]. Pertimbangan aspek teknis dan ekonomis haruslah dipertimbangkan dalam proses perencanaan kapal. Aspek teknis yang perlu dipertimbangkan dalam proses perencanaan suatu kapal ikan mencakup konstruksi kapal, kecepatan kapal, stabilitas, daya motor induk, ukuran utama, tata letak ruangan dan material lambung [5]. Selain itu karakteristik daerah penangkapan ikan (fishing ground) diperairan laut Bandayang tidak menentu, haruslah dikaji secara khusus. Penyimpangan dalam desain dan pembuatan kapal akan menimbulkan dampak negatif bagi keselamatan kapal dan nelayan dalam melaut. Laporan dari Komite Nasional Keselamatan Transportasi (KNKT) tahun 2007-2011 mencatat $59 \%$ kecelakaan dilaut terjadi karena faktorteknis dan $41 \%$ karena faktor manusia (human error) [6].

Dari aspek operasional perikanan tangkap yang selama ini menjadi masalah bagi kapal-kapal pukat cincin yang beroperasi dilaut Banda dengan kondisi laut yang tidak menentu dan ekstrim akan sangat mempengaruhi proses manouver kapal,dalam membentuk lingkaran untuk mengurung dan membatasi pergerakan ikan untuk ditangkap (setting) dan proses penarikkan alat tangkap dan hasil tangkapan dari dalam air (hauling \& purssing). Penempatan hasil tangkapan dan peralatan tangkap di atas geladak kapal dan posisi tinggi tiang jaring sangat berpengaruh terhadap stabilitas kapal.Kondisi yang dialami nelayandi laut yaknisering terjadi kapal mengalami kondisistabilitas kritisyaitu kapal mengalami sudut kemiringan melintang yang besar akibat pengaruhbeban tarik alat tangkap dan hasil tangkapan ikan dari dalam air, serta melakukan manouver dengan kecepatan dalam kurun waktuyang singkat dalam lintasan untuk membentuk lingkaran. Sebagai contoh kasus dimana ketika sudut kemiringan kapal yang makin besar maka operasi penangkapan dihentikan. Dari aspek desain kapal, terlihat bahwa ukurankapal sangat mempengaruhi karakteristik kapal. Jika ukuran lebar kapal lebih kecil maka kapal akan mengalami sudut keolengan yang besar [7].

Kapal penangkap ikan pukat cincin yang beroperasidi perairan laut Banda yang berpangkalan di pelabuhan pendaratan ikan (PPI) Latuhalat, Laha, Hitu dan Waai, umumnyaterbuat dari kayu, dalam pembuatannya tidak melalui proses rancang bangun perkapalan, hanya dilakukan menurut tradisi secara turun temurun. Hal ini sangat berdampak pada pengoperasian kapal tersebut, disamping dalam menghadapi kondisi laut di sekitar daerah penangkapan (fishing ground) yang tidak menentu, sangat mempengaruhi kinerja operasional nelayan, sehingga kadang operasi penangkapan terpaksa dihentikan.

Untuk meningkatkan operasional penangkapan bagi kapal kapal nelayan yang beroperasi di perairan laut Banda dan menjamin keselamatan kapal dan nelayan dilaut maka penelitian ini dilakukan dengantujuan menganalisa kelayakkan karakteristik desain teknis perbandingan ukuran utama kapal dan stabilitasnya. Hasil akhir dari penelitian ini adalah diperolehnya kapal kapal yang memenuhi standar dan yang tidak memenuhi standar desain rancang bangun kapal dengan karakteristik stabilitasnya, sehingga ada yang harus dibenahi proses rancang bangun kapalnya untuk meningkatkan stabilitasnya sehingga kapalnya laik laut.

\section{BAHAN DAN METODE}

Sebagai dasar untuk menganalisa perencanaa kapal pukatcincin yang beroperasi diperairan laut Banda didasarkan pada kriteria parameter standar nilai nilai karakteristik teknis desain kapal yaitu nilai perbandingan ukuran utama kapal dan stabilitas satatis.

Untuk menganalisa karakteristik teknis desain ukuran kapal digunakan nilai rasio kapal sebagai berikut:

- Nilai rasio ukuran utama Kapal [5,8,9] untuk mengetahui:

- Kecepatan dan tahanan kapal dengan standar nilai perbandingan $\mathrm{L} / \mathrm{B}=3,10-4,30$

- Kekuatan memanjang kapal dengan standar nilai perbandingan $\mathrm{L} / \mathrm{D}=9.50-11.00$

- Stabilitas dan manover kapal dengan standar nilai perbandingan $\mathrm{B} / \mathrm{D}=2.10-5.00$

- Analisa ukuran kapal dan mengklasifikasinya digunakan sesuai Keputusan Menteri Kelautan dan Perikanan No 10 pasal 16 ayat 3a. Perhitungan ukuran besarnya kapal ikan ditetapkan dalam ukuran Gross tonnage (GT) [10]. Untuk panjang kapal lebih kecil dari 24 meter, dihitung dengan persamaan berikut: 


$$
\text { Gross Tonage }: \mathrm{GT}=\frac{L \cdot B \cdot D \cdot C B}{2.83}
$$

Untuk menganalisa karakteristik parameter desain stabilitas statis kapal - kapal pukat cincindigunakan persamaan menurut $[11,12]$.

Stabilitas kapal adalah kemampuankapal untuk kembali ke posisi semulasesudah mengalami kemiringan akibat gaya gaya terhadap kapal [13], Fyson, mengatakan sebuah kapal dapat dikatakan stabil jika kapal tersebut dapat kembali ke posisi tegak setelah mendapat tekanan dan gaya sementara [5]. Menurut Munro Smith, 1975 terdapat dua gaya yang bekerja secara berlawanan, yang mempengaruhi stabilitas kapal. Pertama adalah gaya berat dari kapal yang menekan ke bawah melalui titik berat $(\mathrm{G})$ dan gaya apung yang menekan ke atas melalui titik apung (B). Untuk menganalisa stabilitas kapal sesuai dengan gaya-gaya yang dapat mempengaruhi stabilitas di atas, maka akan dihitung posisi titik-titik stabilitas dan waktu periode oleng kapal dengan rumus [11, 12] sebagai berikut:

- Jarak titik apung ke Lunas

$$
\mathrm{KB}=\mathrm{d}\left(0.829-0.343 \times \frac{C B}{C W}\right)(\mathrm{m})
$$

- Jarak titik berat ke Lunas

$$
\mathrm{KG}=0.7 \mathrm{D} \text { (meter) }
$$

- Jarak titik apung ke metasenter

$$
\mathrm{BM}=\frac{B^{2}}{12} \text { (meter) }
$$

- Tinggi Metasenter

$$
\mathrm{GM}=\mathrm{KB}+\mathrm{BM}-\mathrm{KG} \text { ( meter ) }
$$

- Periode Oleng

$$
\mathrm{TR}=\frac{0.9 B}{\sqrt{G M}}
$$

dimana :

$$
\begin{array}{ll}
\mathrm{d} & =\text { Tinggi sarat air }(\mathrm{m}) \\
\mathrm{B} & =\operatorname{Lebar} \operatorname{kapal}(\mathrm{m}) \\
\mathrm{D} & =\text { Dalam kapal }(\mathrm{m}) \\
\mathrm{GM} & =\text { Tinggi metasenter }(\mathrm{m}) \\
\mathrm{CB} & =\text { Koefisien blok } \\
\mathrm{CW} & =\text { Koefisien garis air }
\end{array}
$$

Analisis karakteristik parameter desain stabilitas statis kapal adalah untuk mengetahuikemampuan stabilitaskapaldengan parameter tinggi metasenter (GM) dan waktu periode oleng kapal (TR). Standard nilai untukmenganalisa karakteristik parameter stabilitas statis desain metasenterkapal pukat cincin ditetapkan menurut $[14,15]$

$$
\mathrm{GM}=0.35-0.77 \text { meter }
$$

Standard nilai untuk menganalisa karakteristik parameter waktu periode oleng kapal pukat cincin ditetapkan menurut $[8,16]$. TR $=4.5-7.0$ detik
Penelitian dilakukan di Pulau Ambon pada kapal-kapal pukat cincin yang berpangkalan di pelabuhan pendaratan ikan (PPI) Latuhalat, Laha, Hitu dan Waai yang beroperasi diperairan laut Banda dari bulan Januari-Juni 2018. Lokasi penelitiannya dapat dilihat pada Gambar 1.

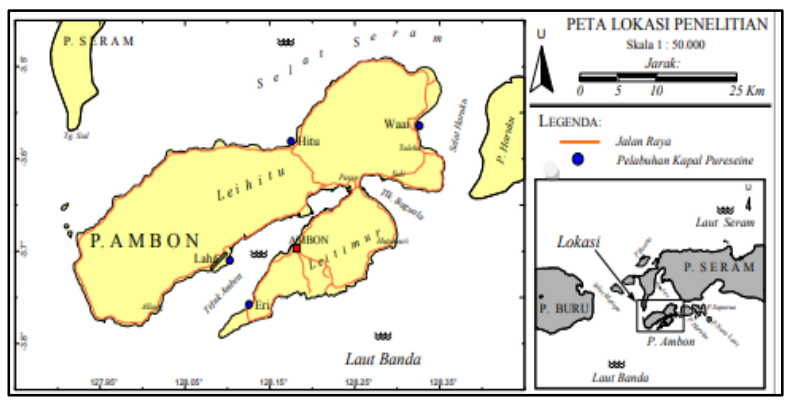

Gambar 1. Peta lokasi penelitian

Teknik pengumpulan data dilakukan sesuai pengamatan dan pengukuran kapal dilapangan, serta wawancara guna memperoleh data primer, dan pengutipan informasi dari berbagai tulisan ilmiah sesuai judul penelitian untuk memperoleh data sekunder.

Untuk memperoleh data primer pengambilan sampel dilakukan terhadap 45 kapal pukat cincin yang melakukan operasi penangkapan ikan diperairan laut Banda yang berpangkalan PPI desa Hitu, Waai, Laha dan Latuhalat untuk mendapatkan ukuran utama kapal dan tinggi sarat kapal. Alat dan bahan yang digunakan meter roll 25 meter, tali PE diameter $2 \mathrm{~mm}$, bambu/gala, kertas gambar, alat tulis/gambar, pemberat, snorkeling dan komputer.

\section{HASIL DAN PEMBAHASAN}

Kapal pukat cincin yang beroperasi di perairan laut Banda mempunyai karakertistik ukuran kapal yang beragam (Gambar 2) Klasifikasi ukuran panjang kapal [8] untuk panjang kapal lebih kecil dari 20 meter terdapat 28 kapal dan untuk ukuran panjang kapal lebih besar dari 20 meter sebanyak 17 kapal.

Dari tabel 1 terlihat konsentrasi ukuran kapal penelitian pukat cincin yang beroperasi perairan laut Banda dengan panjang kapal lebih kecil dari 20 meter, jumlah terbesar berada pada lokasi perairan Latuhalat, dengan jumlah 14 kapal, sedangkan jumlah ukuran terkecil dari panjang kapal terdapat di Laha dengan 5 kapal. Kapal pukat cincin dengan panjang lebih besar dari 20 meter jumlah terbesar terdapat di Waai dengan jumlah 8 kapal dan ukuran terkecil terdapat di Laha dengan jumlah 4 kapal. 
Tabel 1. Ukuran pokok kapal pukat cincin

\begin{tabular}{|c|c|c|c|c|c|c|}
\hline \multirow{2}{*}{$\mathrm{NO}$} & \multirow{2}{*}{ NAMA KAPAL } & \multicolumn{5}{|c|}{ UKURAN UTAMA KAPAL ( M ) } \\
\hline & & LOA & LBP & B & $\mathrm{D}$ & $\mathrm{T}$ \\
\hline 1 & 2 & 3 & 4 & 5 & 6 & 7 \\
\hline 1 & ALFI & 17 & 15 & 2.7 & 1.5 & 1 \\
\hline 2 & ULUPUTIH 01 & 17 & 15.6 & 2.25 & 1.25 & 0.75 \\
\hline 3 & FAJAR ANGADA & 17 & 15.5 & 2.6 & 1.2 & 0.7 \\
\hline 4 & GARUDA 05 & 17 & 16.6 & 3.3 & 1.25 & 0.75 \\
\hline 5 & GARUDA 02 & 17 & 15.4 & 3.25 & 1.25 & 0.75 \\
\hline 6 & DEWARUCI 02 & 19 & 17.5 & 3.6 & 1.5 & 1 \\
\hline 7 & MANUSELA & 19 & 17 & 3 & 2 & 1.5 \\
\hline 8 & DEWARUCI 03 & 19.5 & 18 & 3.2 & 2 & 1.5 \\
\hline 9 & WAINDUA & 19.5 & 17.6 & 3.25 & 2.25 & 1.75 \\
\hline 10 & PANDO & 17 & 16.2 & 3.1 & 1.27 & 0.8 \\
\hline 11 & LAHA 005 & 19.5 & 17 & 3 & 1.5 & 1.5 \\
\hline 12 & PKS & 19 & 18.2 & 5 & 1.75 & 1.25 \\
\hline 13 & LAHA 07 & 19 & 17.5 & 3.4 & 2.5 & 2 \\
\hline 14 & AJAN MIMI & 15 & 14 & 3 & 1.8 & 1.3 \\
\hline 15 & KM BERKAT & 17.5 & 16.2 & 2.8 & 1.25 & 0.75 \\
\hline 16 & GPI 05 & 14 & 12.5 & 3 & 1.5 & 1 \\
\hline 17 & BARISTA & 17 & 15.5 & 3.2 & 1.2 & 0.7 \\
\hline 18 & FAJAR 01 & 19 & 17.5 & 3 & 1.3 & 0.8 \\
\hline 19 & SAM SAN 01 & 19.5 & 18 & 3 & 1.2 & 0.7 \\
\hline 20 & KM 007 & 17.5 & 16 & 3 & 1.4 & 0.9 \\
\hline 21 & ADE YENNY & 17.5 & 16 & 3 & 1.5 & 1 \\
\hline 22 & TRIUMP & 17.5 & 16 & 3.2 & 1.3 & 0.8 \\
\hline 23 & MIO 02 & 17 & 15 & 3 & 1.5 & 1 \\
\hline 24 & RISNA 07 & 17 & 16.5 & 3 & 1.8 & 1.3 \\
\hline 25 & KM FINA & 17 & 15.5 & 2.8 & 1.75 & 1.25 \\
\hline 26 & RISNA 007 & 17 & 15.8 & 3.2 & 1.5 & 1 \\
\hline 27 & KM FIBER 05 & 17 & 15.5 & 3.2 & 1.4 & 0.9 \\
\hline 28 & WILSON & 17.5 & 16.4 & 3.85 & 1.8 & 1.3 \\
\hline 29 & DWIFIN & 21 & 19.5 & 3.1 & 1.75 & 1.25 \\
\hline 30 & MANUWAI 02 & 22.5 & 21 & 3.85 & 1.6 & 1.1 \\
\hline 31 & LEXTINA & 21 & 18.5 & 3.6 & 1.5 & 1 \\
\hline 32 & CHRISLY & 20.1 & 17.5 & 3.1 & 1.8 & 1.3 \\
\hline 33 & MANUSI INDAH & 22.5 & 21.6 & 4.15 & 1.8 & 1.3 \\
\hline 34 & MANU INDAH & 23.2 & 18 & 4.85 & 2.15 & 1.55 \\
\hline 35 & MANUWAI 01 & 23 & 21.5 & 4.15 & 1.8 & 1.3 \\
\hline 36 & PERIKANAN 01 & 20.2 & 18 & 4.2 & 1.76 & 1.26 \\
\hline 37 & LAHA 002 & 21 & 18.2 & 2.9 & 1.8 & 0.8 \\
\hline 38 & LAHA 006 & 22 & 19 & 3.4 & 2 & 1.25 \\
\hline 39 & LAHA 009 & 21 & 18.6 & 3.5 & 2.4 & 2.2 \\
\hline 40 & PERIKANAN 02 & 20.2 & 18 & 4.2 & 1.76 & 1.26 \\
\hline 41 & WAILUA 01 & 21 & 19.5 & 3.5 & 2 & 1.5 \\
\hline 42 & YABA HITU & 21.5 & 20 & 3.5 & 2.5 & 2 \\
\hline 43 & ULUPUTIH 02 & 21 & 19.2 & 3.2 & 2.25 & 1.75 \\
\hline 44 & TIMI NUSA & 23 & 21 & 3.25 & 2 & 1.5 \\
\hline 45 & WAAILUA 02 & 21 & 19.5 & 3.3 & 2.25 & 1.75 \\
\hline
\end{tabular}

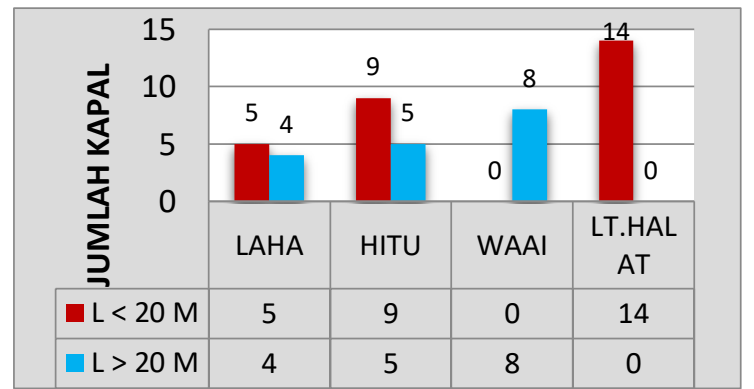

Gambar 2. Klasifikasi Ukuran kapal Pukat Cincin yang beroperasi di laut Banda

\subsection{Rasio Ukuran Pokok Kapal}

Hasil perhitungan ukuran tonase kapal (Tabel 2) memperlihatkan bahwa kapal pukat cincin yang beroperasi perairan laut banda berkisar antara 10 - 50 GT. Sebaran ukuran ini dapat dikatagorikan dalam tonase $10-20$ GT sebanyak 22 unit, 21 30 GT sebanyak 13 unit, 31 - 50 GT sebanyak 10 unit. Sebaran ukuran tonase kapal menunjukkan ukuran 10 - 20 GT mendominasi kapal pukat cincin yang beroperasi di perairan laut Banda. Hasil perbandingan ukuran utama kapal memberikan nilai karakteristik teknis desain untuk mengevaluasi apakah kapal pukat cincin yang beroperasi di perairan laut Banda layak atau tidak layak untuk dapat beroperasi dan dapat menjamin keselamatan kapal dan nelayan selama melaut. Tabel 2 memperlihatkan bahwa rasio L/B yang memenuhi standar untuk tonase $10-50 \mathrm{GT}$ adalah 4 kapal. Rasio L/D yang memenuhi standar untuk ukuran tonase $10-20$ GT adalah 6 kapal. Rasio B/D yang memenuhi standar untuk ukuran tonase $10-20 \mathrm{GT}$ adalah $16 \mathrm{kapal}$, untuk tonase 21 - 30 GT terdapat 4 kapal, dan untuk tonase 31 - 50 GT terdapat 4 kapal.

Tabel 2. Karakteristik perbandingan ukuran kapal pukat cincin

\begin{tabular}{|c|c|c|c|c|}
\hline \multirow{2}{*}{$\begin{array}{l}\text { NO. } \\
\text { KAPAL }\end{array}$} & \multirow{2}{*}{$\begin{array}{c}\text { GT } \\
\text { KAPAL }\end{array}$} & \multicolumn{3}{|c|}{$\begin{array}{c}\text { NILAI PERBANDINGAN UKURAN } \\
\text { POKOK KAPAL }\end{array}$} \\
\hline & & $\mathrm{L} / \mathrm{B}$ & $\mathrm{L} / \mathrm{D}$ & $\mathrm{B} / \mathrm{D}$ \\
\hline 1 & 2 & 3 & 4 & 5 \\
\hline 1 & 10 & 5.55 & 10 & 1.8 \\
\hline 2 & 10 & 6.93 & 12.48 & 1.75 \\
\hline 3 & 11 & 5.96 & 12.92 & 2.16 \\
\hline 4 & 14 & 5.03 & 13.28 & 2.64 \\
\hline 5 & 15 & 4.74 & 12.32 & 2.6 \\
\hline 6 & 21 & 4.86 & 11.67 & 2.4 \\
\hline 7 & 23 & 5.67 & 8.5 & 1.5 \\
\hline 8 & 26 & 5.62 & 9 & 1.6 \\
\hline 9 & 29 & 5.42 & 7.82 & 1.44 \\
\hline 10 & 13 & 5.23 & 12.76 & 2.44 \\
\hline 11 & 18 & 5.66 & 11.33 & 2 \\
\hline 12 & 14 & 1.64 & 5.46 & 3.33 \\
\hline 13 & 29 & 5.14 & 7 & 1.36 \\
\hline 14 & 14 & 4.67 & 9.33 & 2 \\
\hline 15 & 12 & 5.78 & 12.96 & 2.24 \\
\hline 16 & 13 & 4.16 & 8.33 & 2 \\
\hline 17 & 14 & 4.84 & 12.92 & 2.66 \\
\hline 18 & 15 & 5.83 & 13.46 & 2 \\
\hline 19 & 15 & 6 & 15 & 2.5 \\
\hline 20 & 15 & 5.33 & 11.43 & 1.66 \\
\hline 21 & 16 & 5.33 & 10.67 & 2.14 \\
\hline 22 & 16 & 5 & 12.31 & 2.46 \\
\hline 23 & 16 & 5 & 10 & 2 \\
\hline 24 & 17 & 4.94 & 10.53 & 2.13 \\
\hline 25 & 18 & 5.54 & 8.86 & 1.6 \\
\hline 26 & 19 & 5.5 & 9.17 & 1.66 \\
\hline 27 & 16 & 4.84 & 11.07 & 2.28 \\
\hline 28 & 23 & 4.26 & 9.11 & 2.14 \\
\hline 29 & 23 & 6.29 & 15.6 & 1.77 \\
\hline 30 & 29 & 5.44 & 13.12 & 2.41 \\
\hline 31 & 24 & 5.14 & 12.33 & 2.4 \\
\hline 32 & 25 & 5.64 & 9.72 & 1.72 \\
\hline 33 & 34 & 5.21 & 12 & 2.31 \\
\hline 34 & 47 & 3.71 & 8.37 & 2.25 \\
\hline 35 & 36 & 5.81 & 11.94 & 2.31 \\
\hline 36 & 31 & 6.13 & 10.86 & 2.38 \\
\hline 37 & 20 & 6.27 & 10.11 & 1.61 \\
\hline 38 & 27 & 5.58 & 9.5 & 1.7 \\
\hline 39 & 34 & 5.31 & 7.75 & 1.45 \\
\hline 40 & 23 & 6.12 & 10.85 & 1.71 \\
\hline 41 & 30 & 6.93 & 12.48 & 1.75 \\
\hline 42 & 40 & 5.74 & 8 & 1.4 \\
\hline 43 & 31 & 4.86 & 11.67 & 1.42 \\
\hline 44 & 32 & 6.46 & 10.5 & 1.62 \\
\hline 45 & 32 & 5.01 & 8.67 & 1.47 \\
\hline
\end{tabular}


Hasil perhitungan pada Tabel 2 menunjukan semua kapal pukat cincin yang melaut di perairan Banda belum memenuhi keempat standar rasio ukuran pokok kapal. Untuk nilai perbandingan L/B sebagian besar tidak memenuhi standar desain kapal karena terdapat 36 kapal dengan rasio L/B $80 \%$ lebih besar dari standar, diikuti dengan nilai perbandingan L/D 23 kapal, mempunyai $15 \%$ ratio lebih kecil dari standard dan $51 \%$ ratio lebih besar dari standar. Terdapat B/D 21 kapal dengan ratio $46.67 \%$ lebih kecil dari standar. Sedangkan kapal dengan nilai perbandingan yang memenuhi standar adalah $\mathrm{B} / \mathrm{D}$ $=24 \mathrm{kapal}, \mathrm{L} / \mathrm{D}=15 \mathrm{kapal}$ dan $\mathrm{L} / \mathrm{B}=4 \mathrm{kapal}$.

\subsection{Analisa Rasio Ukuran Utama Kapal}

Nilai perbandingan lebar dan tinggi geladak kapal digunakan untuk menganalisa stabilitas, kemampuan olah gerak dan manover kapal [7] Standar nilai perbandingan B/D ditetapkan menurut jenis kapal ikan pukat cincin dengan nilai perbandingan untuk panjang kapal lebih kecil dari 22 meter nilai $\mathrm{B} / \mathrm{D}=2.10-5.00$ dengan rataan $\mathrm{B} / \mathrm{D}=3.0$. Dari hasil perhitungan nilai perbandingan $\mathrm{B} / \mathrm{D}$ untuk 45 kapal pukat cincin yang beroperasi diperairan laut Banda diketahui nilai perbandingan $\mathrm{B} / \mathrm{D}=2.21$, hasil ini terbukti lebih kecil dari nilai rata rata $B / D$ standar. Apabila dibandingkan dengan nilai B/D kapalkapal pukat cincin yang berpangkalan di perairan Bitung dengan rasio $\mathrm{B} / \mathrm{D}=2.62$ [17] sehingga kapal pukat cincin di perairan laut Banda masih lebih kecil, menunjukkan tinggi sampai geladak kapalnya lebih besar sehingga turut mempengaruhi stabilitas dan manover kapal. Untuk meningkatkan nilai perbandingan karakteristik desain B/D yang lebih kecil tersebut adalah dengan menambah lebar kapal sehingga stabilitas dan manovernya semakin baik.Analisa Stabilitas Statis Kapal

\section{- Parameter Stabilitas GM \& TR}

Karakteristik teknis desain stabilitas satatis adalah untuk menunjukkan kemampuan stabilitas kapal yang dihitung pada kondisi air tenang dengan tanpa muatan atau deplasemen kapal kosong. Hasil perhitungan tinggi metasenter (GM) dan waktu peroide oleng kapal (TR) yang akan menunjukkan apakah stabilitas kapalnya terlihat stabil, netral atau tidak stabil.

Karakteristik parameter stabilitas kapal pukat cincin yang beroperasi di perairan laut Banda diperlihatkan pada Tabel 3. Hasil perhitungan menunjukkan bahwa nilai KG berkisar antara 0,84 $-1,57$ meter, nilai KM berkisar antara 0,92 - 2.1 meter. Nilai GM berkisar antara 0,00- 0,80 meter, dan nilai TR (waktu periode oleng kapal) berkisar antara 2,97-9.54 detik.

\section{- Tinggi Metasenter (GM)}

Tinggi metasenter adalah jarak antara titik berat (B) dengan titik metasenter (M), titik ini dapat berubah sesuai dengan kemiringan kapal. Sebuah kapal dinyatakan stabil apabila titik GM lebih besar dari 0 . Standard stabilitas GM untuk kapal ikan menurut [14] lebih besar dari 0.35 meter.Menurut [15], $\mathrm{GM}=0.7-0.77$ meter. Sebagai standar adalah $0.35-0.77$ meter. Tinggi titik GM untuk 45 kapal yang beroperasi diperairan laut Banda dengan klasifikasi $10-50$ GT, terdapat 11 kapal dengan tonase $10-20$ GT memenuhi standar, stabilitasnya baik (positif) karena posisi titik berat $(\mathrm{G})$ berada dibawah titik M. Terdapat 11 kapal berada dibawah nilai standard GM lebih kecil 0.35 meter, kapalnya tidak stabil atau stabiltas negatif karena titik $G$ berada diatas titik M. Untuk tonase 21-30 GT 4 kapal memenuhi standar, dan 9 kapal nilai GM lebih kecil standar. Untuk tonase 31 - 50 GT 3 kapal memenuhi standar nilai GM, 5 kapal tidak memenuhi standar nilai GM karena lebih kecil dari 0.35 meter. Terdapat 1 kapal dengan nilai $\mathrm{GM}=0$ kapalnya berada dalam kondisi stabilitas netral karena posisi titik $G$ berimpit dengan titik M.Kapal dengan klasifikasi menurut panjang. Untuk ukuran < 20 meter terdapat 13 kapal nilai GM memenuhi standar, 14 kapal nilai GM lebih kecil standar. Untuk ukuran kapal > 20 meter, terdapat 6 kapal memenuhi standar 1 kapal nilai $\mathrm{GM}=0$, terdapat 1 kapal nilai GM lebih besar standar dan 10 kapal nilai GM lebih kecil standar.

Untuk meningkatkan stabilitas kapal untuk tetap pada posisi stabil maka kedudukan titik $\mathrm{G}$ tidak boleh melewati titik Metasenter (M).

\section{- Waktu periode oleng (TR)}

Waktu periode oleng kapal adalah salah satu kriteria desain stabilitas kapal untuk memberikan kenyamanan dan keselamatan nelayan dalam oprasi penangkapan ikan dilaut. Waktu yang dibutuhkan selang periode oleng kapal adalah untuk mengembalikan kapal pada posisi netral setelah mengalami gaya-gaya luar akibat gelombang, angin, arus dan pengaruh alat tangkap dalam operasi penangkapan. Waktu periode oleng kapal perikanan menurut [16] TR = $5.5-7.0$ detik. Menurut [8] untuk kapal ikan, TR $=4.5-7.0$ detik. Sebagai standar ditetapkan TR $=$ $4.5-7$ detk. 
Tabel 3. Karakteristik Parameter Titik Stabilitas

\begin{tabular}{|c|c|c|c|c|c|c|}
\hline \multirow{2}{*}{$\mathrm{NO}$} & \multirow{2}{*}{ GT } & \multicolumn{5}{|c|}{ KARAKTERISTIK POSISI TITIK STABILITAS \& PERIODE OLENGKAPAL } \\
\hline & & $\mathrm{KB}$ & BM & KG & GM & TR \\
\hline 1 & 2 & 3 & 4 & 5 & 7 & 8 \\
\hline 1 & 10 & 0.43 & 0.81 & 0.84 & 0.40 & 3.70 \\
\hline 2 & 10 & 0.46 & 0.56 & 0.87 & 0.15 & 5.27 \\
\hline 3 & 11 & 0.43 & 0.81 & 0.84 & 0.40 & 3.70 \\
\hline 4 & 14 & 0.46 & 1.21 & 0.87 & 0.80 & 3.32 \\
\hline 5 & 15 & 0.46 & 1.17 & 0.87 & 0.76 & 3.35 \\
\hline 6 & 21 & 0.62 & 1.08 & 1.05 & 0.65 & 4.02 \\
\hline 7 & 23 & 0.81 & 0.50 & 1.30 & 0.11 & 8.18 \\
\hline 8 & 26 & 0.93 & 0.50 & 1.30 & 0.13 & 7.50 \\
\hline 9 & 29 & 1.08 & 0.50 & 1.46 & 0.12 & 8.34 \\
\hline 10 & 13 & 0.54 & 1.00 & 0.88 & 0.66 & 3.43 \\
\hline 11 & 18 & 0.54 & 0.75 & 1.05 & 0.24 & 5.51 \\
\hline 12 & 14 & 0.53 & 2.00 & 1.00 & 1.53 & 3.64 \\
\hline 13 & 29 & 1.08 & 0.51 & 1.50 & 0.21 & 6.65 \\
\hline 14 & 14 & 0.54 & 0.75 & 1.00 & 0.29 & 5.00 \\
\hline 15 & 12 & 0.42 & 0.87 & 0.87 & 0.42 & 3.89 \\
\hline 16 & 13 & 0.55 & 0.75 & 1.00 & 0.30 & 4.93 \\
\hline 17 & 14 & 0.54 & 0.77 & 0.84 & 0.41 & 4.50 \\
\hline 18 & 15 & 0.44 & 0.94 & 0.91 & 0.43 & 4.10 \\
\hline 19 & 15 & 0.39 & 0.53 & 0.84 & 0.08 & 9.54 \\
\hline 20 & 15 & 0.50 & 0.83 & 0.98 & 0.35 & 4.56 \\
\hline 21 & 16 & 0.55 & 0.75 & 1.05 & 0.25 & 5.40 \\
\hline 22 & 16 & 0.44 & 1.06 & 0.91 & 0.59 & 3.75 \\
\hline 23 & 16 & 0.55 & 0.75 & 1.05 & 0.35 & 4.87 \\
\hline 24 & 17 & 0.55 & 0.85 & 1.05 & 0.35 & 4.87 \\
\hline 25 & 18 & 0.69 & 0.54 & 1.02 & 0.21 & 5.48 \\
\hline 26 & 19 & 0.55 & 0.85 & 1.05 & 0.35 & 4.87 \\
\hline 27 & 16 & 0.50 & 0.94 & 0.98 & 0.46 & 4.25 \\
\hline 28 & 23 & 0.70 & 0.95 & 1.26 & 0.39 & 5.50 \\
\hline 29 & 23 & 0.67 & 0.64 & 1.22 & 0.09 & 9.30 \\
\hline 30 & 29 & 0.64 & 1.12 & 1.12 & 0.64 & 4.33 \\
\hline 31 & 24 & 0.60 & 1.08 & 1.05 & 0.63 & 4.08 \\
\hline 32 & 25 & 0.77 & 0.62 & 1.26 & 0.13 & 7.74 \\
\hline 33 & 34 & 0.76 & 1.10 & 1.26 & 0.60 & 4.82 \\
\hline 34 & 47 & 0.84 & 1.26 & 1.39 & 0.71 & 5.19 \\
\hline 35 & 36 & 0.76 & 1.10 & 1.26 & 0.60 & 4.82 \\
\hline 36 & 31 & 0.75 & 1.16 & 1.23 & 0.68 & 4.58 \\
\hline 37 & 20 & 0.65 & 0.58 & 0.96 & 0.27 & 5.02 \\
\hline 38 & 27 & 0.81 & 0.64 & 1.20 & 0.25 & 6.12 \\
\hline 39 & 34 & 1.08 & 0.51 & 1.44 & 0.15 & 8.28 \\
\hline 40 & 23 & 0.67 & 0.64 & 1.22 & 0.09 & 9.30 \\
\hline 41 & 30 & 0.93 & 0.68 & 1.40 & 0.21 & 6.87 \\
\hline 42 & 40 & 1.13 & 0.48 & 1.50 & 0.11 & 9.54 \\
\hline 43 & 31 & 1.09 & 0.49 & 1.46 & 0.12 & 8.23 \\
\hline 44 & 32 & 0.59 & 0.80 & 1.20 & 0.19 & 6.72 \\
\hline 45 & 32 & 1.08 & 0.49 & 1.57 & 0.00 & 2.97 \\
\hline
\end{tabular}

Dari hasil perhitungan tabel 3diketahui waktu periode oleng 45 kapal dengan ukuran tonase 10 - 50 GT, dikatagorikan dalam 3 waktu periode oleng kapal yaitu normal, cepat dan lambat. Terdapat 19 kapal dengan waktu normal (stabilitas positif ), 25 kapal dengan waktu yang cepat. Terdapat 1 kapal dengan waktu yang lambat (stabilitas negatif). Waktu periode oleng rata rata standar adalah 5.75 detik, sedangkan waktu rata rata periode oleng kapal pukat cincin yang beroperasi diperairan laut Banda masih lebih kecil yaitu 5.63 detik. Untuk kapal dengan tonase 10 - 30 GT rata rata TR termasuk kapal dengan waktu periode oleng yang cepat atau stabilitas negatif, sehingga menimbulkan ketidak nyamanan bagi nelayan dalam operasional penangkapan. Kapal dengan TR lambat mudah mengalami kecelakaan karena, waktu yang dibutuhkan untuk mengembalikan kapal pada posisi tegak, sangat lambat terutama pada kondisi 
fishing ground dengan cuaca buruk. Untuk kapal dengan panjang lebih besar dari 20 meter waktu rata rata periode olengnya adalah 6.34 detik, TR kapal ini termasuk dalam waktu yang normal dari standar yang ditentukan dan lebih besar 0.71 detik dari waktu TR rata rata standar kapal kapal perikanan. Sehingga kemampuan stabilitas kapal dengan waktu periode olengnya lebih baik dibandingkan kapal dengan ukuran tonase $10-$ $30 \mathrm{GT}$.

\section{KESIMPULAN}

Parameter teknis desain ukuran pokok kapal pukat cincin yang beroperasi di perairan laut Banda belum sepenuhnya memenuhi standar teknis desain. Karakteristik perbandingan L/B, sebagian besar tidak memenuhi standard yaitu $91,11 \%$, demikian rasio $\mathrm{L} / \mathrm{D}$ hanya $66,67 \%$ sedangkan rasio $\mathrm{B} / \mathrm{D}$ adalah $46,67 \%$ tidak memenuhi standar.

Karakteristik parameter stabiliatas statis untuk nilai GM terdapat 26 kapal atau $57.77 \%$ tidak memenuhi standar, sedangkan TR yang memenuhi standar adalah $42.23 \%$.

Untuk meningkatkan stabilitas kapal pada saat kembali dari fishing ground, hasil tangkapan baiknya dimasukan didalam palka ikan.

Untuk meningkatkan operasional penangkapan dan keselamatan kapal dan nelayan dilaut dibutuhkan kerjasama pemerintah, akademisi dan pengrajin kapal untuk membangun kapal ikan sesuai standar desain kapal, khususnya type pukat cincin di Maluku.

\section{DAFTAR PUSTAKA}

[1] WPP. 2019. Potensi 11 wilayah Pengelolaan Perikanan.https://dari laut.id

[2] FAO, Food Agriculture Organization. 2009. The State of Word Fisheries and Aquaculture 2008. Rome (IT)

[3] Ayodhyoa, 1985. Suatu Pengenalan Fishing Gear. Fakultas Perikanan. IPB. Bogor.

[4] Pasaribu, B. P. $1986 . \quad$ Pengembangan Kapal Ikan di Indonesia Dalam Rangka
Implementasi wawasan

e-ISSN 2798-7310

Prosiding.IPB. Bogor

[5] Fyson, J. 1985. Design of Small Fishing Vessels.FAO United Nations. Fishing New book Ltd. Englands

[6] Komisi Nasional Keselamatan Transportasi, 2011. Kajian Analisa Trend Kecelakaan Tranportasi Laut Tahun 2003 2008. KNKT Jakarta.

[7] Poelsh. H. 1979. Ship Design And Ship Theory. Lecture Partly And Repated At Makasar And Ambon

[8] BKI, 2004. Rules for the Clasificaton of Seagoing Steel Ship. PT Bina Cakrawala Utama. Jakarta

[9] Ayodhyoa, 1972.Fishing Boat Correspondece Cource Center. Fakultas Perikanan. IPB. Bogor

[10] Departemen Kelautan Dan Perikanan RI, 2009.Undang Undang Nomor 31 Tahun 2009 Tentang Jenis Kapal Perikanan.Jakarta.

[11] Hind.J.Anthony.1982. Stability And Trim Of Fishing Vessels. Second Edition Fishing News books Ltd. London.

[12] Sarohchman Kusdi, 1981.Perencanaan Dan Pengolahan Kapal Ikan. Fakultas Perikanan. IPB. Bogor.

[13] Nomura,M and Yamazaki,T. 1977.Fishing Techniques. Japan International Agency Tokyo.

[14] Smith Munro. R. 1980. Merchant Ship Design. The University of Liverpool Hutchinson London.

[15] Bhattacharya. R. 1978. Dynamic of Marine Vichcles. Jhon Willey and Son inc,new.

[16] Traung. J. O. 1990. Fishing Boat of the Word, 2. Published by Fishing News (book) England

[17] Saiye,Z.1995. Studi Tentang Beberapa Karakteristik Dinamis Kapal Pukat Cincin Di Kecamatan Bitung, Jurnal. Fakultas Perikanan Universitas Samratulangi. Manado. 